\title{
RESILIENCE AND VULNERABILITY OF HISTORICAL CENTERS: THE CASE OF THE DISTRICT OF CAMERINO IN THE MARCHE REGION
}

\author{
E. PETRUCCI ${ }^{1}$, L. BARCHETTA ${ }^{2 *}$ AND D. LAPUCCI ${ }^{2}$ \\ ${ }^{1}$ University of Camerino, School of Architecture and Design \\ Viale della Rimembranza, 63100 Ascoli Piceno, Italy \\ e-mail: enrica.petrucci@unicam.it \\ ${ }^{2}$ University of Camerino, School of Architecture and Design \\ Viale della Rimembranza, 63100 Ascoli Piceno, Italy \\ e-mail: lucia.barchetta@unicam.it (*corresponding author) \\ diana.lapucci@unicam.it
}

Keywords: Historical Centers, Masonry, Earthquake, Resilience

\begin{abstract}
The seismic events that hit central Italy in 2016, causing extensive damage to cultural heritage and the loss of entire villages, showed the extreme fragility of the Marche territorial system with strong repercussions on the economic and social development. In the historic villages, the high inherent seismic vulnerability of the building makes it difficult to apply regulations oriented to the protection and preservation of historical and cultural values: strategies for the recovery of the buildings seem very complex. The historical building is generally characterized by a high building density, a scarcity of urban voids and an articulated accessibility system. In recent years the Marche region has developed, due to the intensification of earthquakes, a particular susceptibility to seismic risk. The historic centres have shown a scarce capability to adaptation and difficulties in hypothesizing new scenarios after the damage. In this context, we want to define an analytical method of the systemic vulnerability in the historical centres; this vulnerability is considered as a result of the complex interaction of individual structural units, aggregates and urban spaces. The aim is to compare this vulnerability with the effects that the earthquake really had on the buildings: the knowledge of the real behaviour in the historic centres will guide the research towards the definition of actions aimed at the mitigation of the seismic risk through the reduction of intrinsic vulnerabilities in the building and the implementation of the capability to face the earthquake, in order to develop a "new resilience". The district of Camerino is taken as a case study; it's a territorial hub of services and activities as well as being one of the largest inhabited centres affected by the 2016-2017 earthquake.
\end{abstract}




\section{INTRODUCTION}

The concept of resilience is used more and more frequently in the debate around risk reduction and in processes of transformation, regeneration, development of the territory that disasters force to apply efficiently.

The term resilience refers to the change of approach deemed necessary to continue guaranteeing sustainability prospects related to changes. In research aimed at mitigating territorial risks, the concept of resilience assumes a central role in the construction of strategies aimed at disaster risk reduction with a plurality of objectives related to territorial quality. In the urban context, it seems impossible to talk about resilience without investigating the aspect of vulnerability [1]. The city, in particular the historical one, is an asset exposed to risk, weak and vulnerable: the aim is the reduction of urban vulnerability through risk control and management considered as the improvement of urban resilience as the ability to respond and adapt to the phenomenon suffered by the urban system itself [2].

The earthquake that recently hit the regions of central Italy and in particular the Marche hinterland requires the development of new observations. The enormous loss of human lives, the seriousness of the destruction, the vastness of the affected area and the need for a rapid reconstruction require reconsidering issues such in the process of the abandonment of the internal area, already started before the earthquake. Although we are looking for references in history, we are unable to trace a reconstructive model especially as regards the intervention in historic centres which are generally more damaged by seismic events [3]. The main aim of the

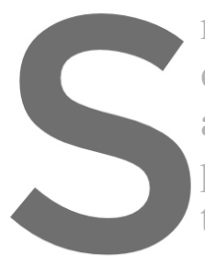
research is, therefore. capacities of the histori and vulnerable, without a preserved and valued. the typical and specific
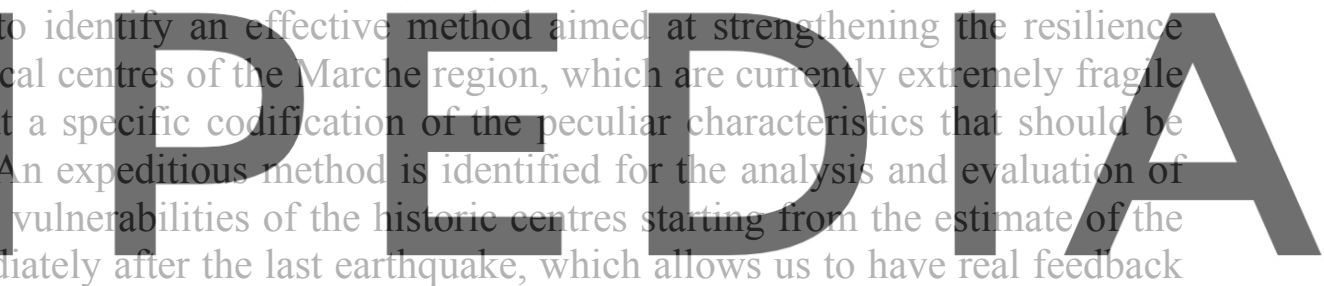
on which to base forecasts and methodologies of intervention

Register for free at https//www.scipedia.com to download the version without the watermark

\section{THE HWSTORICAL CENTRES OF THE MARCHE REGION}

The historical centres of the Marche region, like most of the Italian centres, are born with typical structural concepts of the time of construction, however, they evolve over time according to growth and transformation processes that change their original shape. These evolutions often involve the presence of different construction materials and technologies. These factors determine a certain difficulty in identifying the "assembly" processes of multiple structural units interacting with each other. In fact, a building cluster is made up of multiple parts that are the result of an articulated and non-unitary genesis, due to different factors (construction sequence, change of materials, changed needs, changes of owners, etc.) [4]. Analyzing a building belonging to a cluster; therefore, it is necessary to take into account the possible interactions deriving from the structural contiguity with the adjacent buildings, connected or in adherence to it. This complexity makes the correct knowledge of the structural system that composes it difficult, but necessary. As part of the research on the historic centres of the Marche region, it is essential to deepen the issues concerning urban morphology considered in its historical evolution. The absence of a recognized cognitive approach, 
unfortunately, makes the dissertation uncertain: an attempt has therefore been made to characterize the historic centres of the Marche as far as possible. The identification of a territorial type, intended as the recurrence of physical elements but also of culture and language that link the settlements present in a given geographical context, arouses some interest. They have the essential prerogative to have been built within the perimeter walls delimiting the urban core which often had a natural defensive function [5]. In almost all cases, historical centres in the Marche region can be differentiated into two main types:

1) Urban cores with pre-medieval phases:

- Pre-existence of an organized form of the current urban centre dating back to remote ages

(Roman or previous classicism);

- Subsequent urban development of the late ancient or early medieval period.

2) Urban cores with a new medieval foundation:

- Closely related to the morphology of the territory;

- Articulated morphological schemes:

- A propensity to use masonry cells organized in compact blocks.

The Marche Region is characterized by a territory that is divided into three bands parallel to the Adriatic Sea. The inland areas are the most fragile. As a matter of fact. even before the seismic events, the historic centres located in the hinterland had had to face a series of difficulties, related to the phenomenon of abandonment, of depopulation of young people with low generational turnover. These phenomena were also accentuated hydrogeological instabilities and the presence of weak infrastructures. Three years after the earthquake, the most
affected historical centres, when not completely destroyed, are impossible to adcess, most of
the people who used to live there moved mostly along the coast where services and
infrastructures are more efficient, commercial activities are located and concentrated in
temporary structures, with an exponential acceleration of the depopulation processes that were
already underway. In this research, the historical centre of Canierino is analyzed, a city heavily affected by the earthquake in Central Italy 2016.

Register for free at https//www.scipedia.com to download the version without the watermark 3 BRIEF HISTORY AND SEISMICITY OF CAMIERINO

The toponym Camerinum is attested by classical and medieval sources but some recent studies have delineated its most ancient phases, identifiable in prehistoric and protohistoric times, according to typical settlement models, entirely analogous to the nearby plestine context. The hill where the historic centre of the city of Camerino rises, which dominates the surrounding area, has been inhabited without interruption until today, creating a settlement stratification; this, if on the one hand severely compromised the full understanding of the previous phases, proves the favourable location of the site. Here the discoveries of prehistoric and protohistoric age are rare, while more frequent are the discoveries that attest to proto-urban forms starting from the fourth century. BC. Around the end of the 1st century BC a.C., perhaps in conjunction with the territorial reorganization of the Augustan age, this urban area also seems to have undergone a significant transformation with the construction of large domus, which remain until the late ancient era. In the Roman age, Camerino assumed an important role, as evidenced by the alliance agreement (aequum foedus) stipulated with Rome in $309 \mathrm{BC}$. The religious tradition preserved the memory of the siege that Alaric placed in the city in 409. After the defeat the Goths in 553, it became part of the Byzantine exarchate and in 592, with the 
Lombard conquest, Camerino gave the name to a duchy incorporated into the one of Spoleto (VI-VIII century). It was already a bishopric in 465 and it had a vast ecclesiastical jurisdiction for over a millennium. Carlomagno elected Camerino as the capital of the homonymous marca, which extended from the Apennines to the Adriatic. After 1198 it became part of the domains of the Church, maintaining its autonomy. During the first half of the century XIII fiercely defended the Guelph side against the Swabians. It was destroyed by Manfredi's troops (1259). After a short period of abandonment, the area was recovered with new urban arrangements. Under the Lordship of the Da Varano family, which lasted until the mid-sixteenth century, Camerino knows a period of intense political and cultural vitality and economic prosperity with a significant population increase. These positive factors, combined with a significant urban transformation, changed the layout of medieval townhouses. From 1545 the city returned under the direct dominion of the Church with the function of the capital of the Apostolic Delegation. Thus, began a long phase of political and social stability, but also of silent decline. The bishops, in the last decades of the sixteenth century, built their palace, facing the ducal one. Until the French invasion, history was free of significant events. The history of the 1600 s was articulated with the multiplicity of particular statutes.
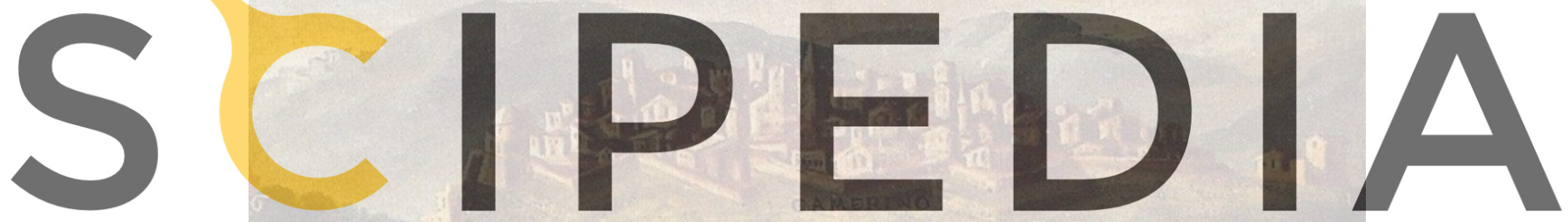

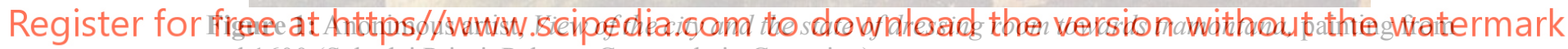
around 1600 (Sala dei Priori, Palazzo Comunale in Camerino)

The state was divided into more than 100 communities, run by 3 vicariates. In the eighteenth century, Camerino was reduced to a large agricultural village with a limited economy and some industry in the area. During the French occupation, Camerino was aggregated to the Tronto department. In 1799, due to the reaction of the insurgents, the city was at the centre of various struggles, until on July 28,1799 , it was devastated by a serious earthquake that caused death and destruction. In 1809, during the Napoleonic era, the city was incorporated with the other marches of Fermo and Ancona, becoming the district capital. The Austrian invasion that followed the Napoleonic government desolated the territory even more. The Return of the Papal States was therefore welcomed with sincere enthusiasm; it gave Camerino a period of tranquillity and order but was unable to recover the city from its decline. Famine followed (1816-1817). In 1860 it was annexed to the Kingdom of Italy [6].

The historical events are intertwined with the changes in the urban layout of the city, starting from the early Middle Ages, with evident medieval and Renaissance transformations; these are works that go up to the modern age, also characterized by reconstructions following some disastrous seismic events: this makes the identification of recurrent constructive methods more 
complex. The knowledge of the local seismic history is known only from 1279; there are numerous events which confirm that the high seismic susceptibility of the area, which was also affected by earthquakes with epicentres in the central and central-southern Apennines.

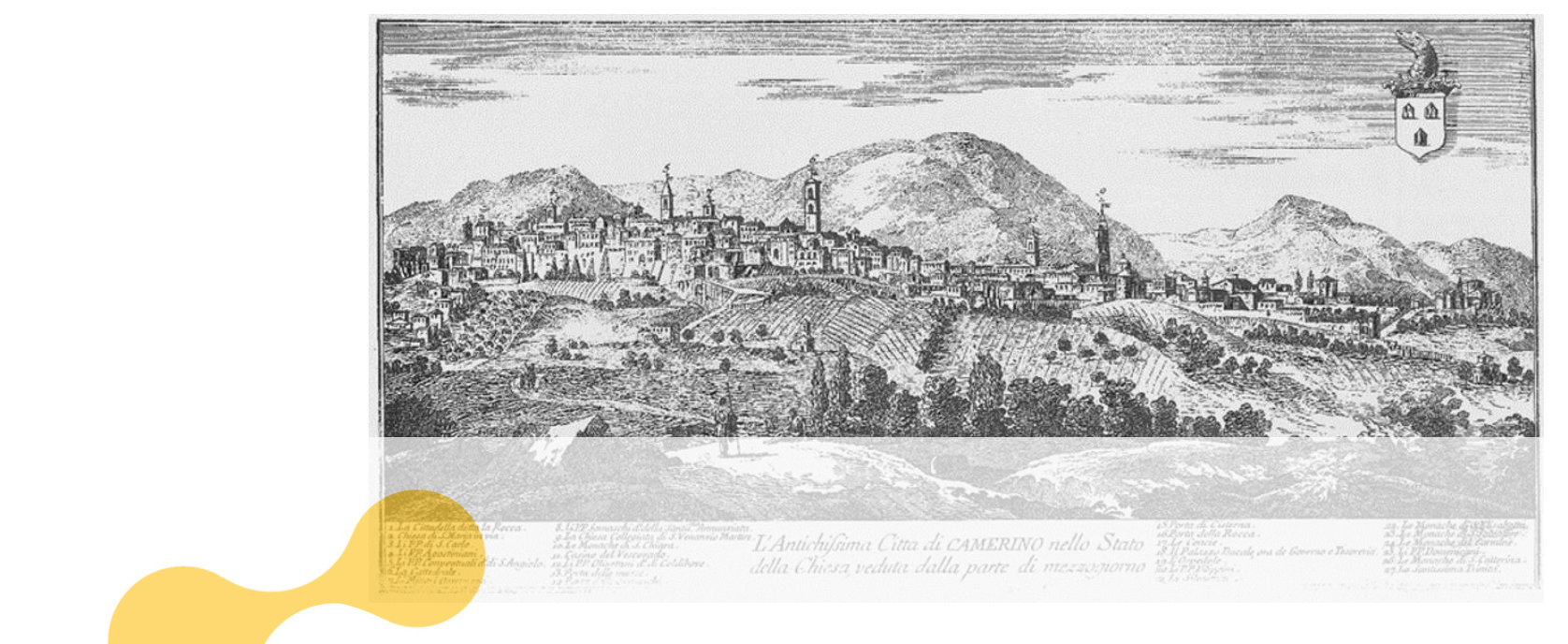

Figure 2: Salmon T., The Ancient City of Camerino in the State of the Church seen from the south side, engraving from around 1750 .

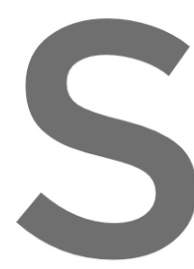

Figure 3 shows the most significant events, excludir Marche Appennines, the epicentre in the Cameri and finally the one in 1997

\section{Most of the oldest buitdings in the area and}

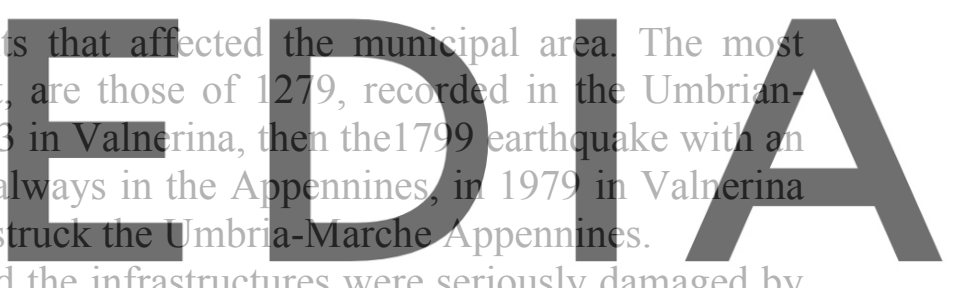

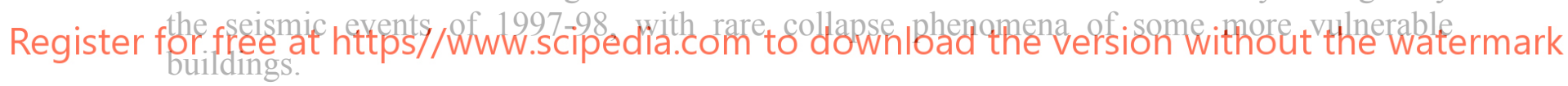

CPTI15-DBMI15 - Camerino

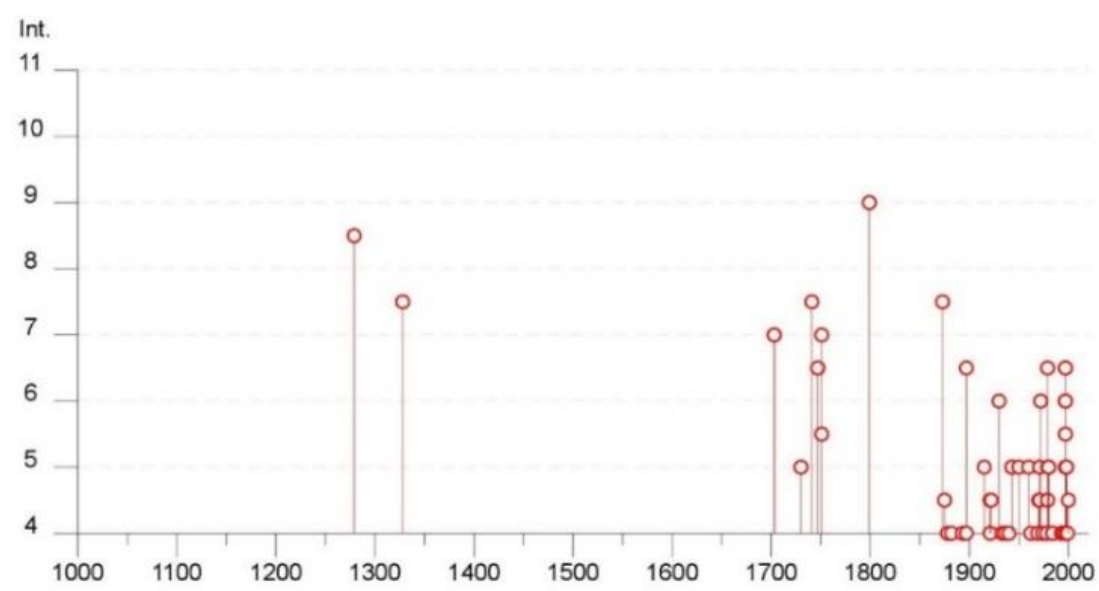

Figure 3: List of historical Earthquakes by INGV site http://www.mi.ingv.it/terremoti-storici/ [view on 28.01.2020] 
Starting from the historical sequence of the earthquakes that affected the territory of Camerino, three events have been identified that caused significant damage; on them, it is possible to perform a damage analysis, in order to have a map of the effects that every single event had on the historical buildings. These are the earthquake of 1799, the one of 1997/98 and the last one in 2016-2017. As regards the earthquake of 1799, historical research has been done at the state archive of Camerino. The documents available refer to the reports drawn up by the architect Andrea Vici in 1800, who compiles a careful description of the damage and interventions to be performed on buildings of particular importance; in addition, associated the evaluation of the costs related to the repairs of the damages occurred in the whole historical centre. This information is also reported in the recovery plan drawn up for the city of Camerino after the earthquake of 1997-98. The latter reports a precise mapping of the damages found and an assessment of the specific vulnerabilities.

After the 2016 earthquake, all the Cultural Heritage was highly damaged and, in some cases, collapsed with consequent loss of the building. The historic centre is seriously damaged so as to make it inaccessible to citizens. The first shock, which occurred on the night of August 24th, 2016 with magnitude 6.0 and Accumoli epicentre (about $51 \mathrm{~km}$ from Camerino), caused about 300 victims in Lazio and Marche regions, devastating the inhabited centres of Amatrice, Accumoli, Peseara del Tronto and Arquata del Tronto. In Camerino there were no victims and, with the first shock, the damages were almost zero except for some injury or slight collapse of some historic buildings such as the cathedral. On October 26th, two big shocks were detected, both with an epicentre in Castelsantangelo sul Nera (about $28 \mathrm{~km}$ from Camerino); the first at 19:10 of magnitude 5 the inhabitants of the intensity, led to the coll bell tower of the church of Santa Maria in Via, families fortunately outside because of fear. Such
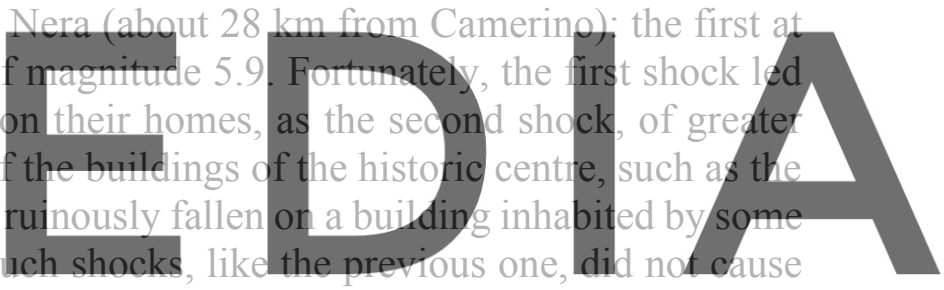

victims, but the intensity of the damage could not be recorded due to a further shock that

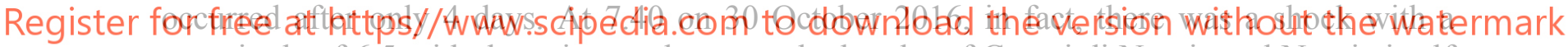
magnitude of 6.5 with the epicentre between the hamlet of Campi di Norcia and Norcia itself (about $28 \mathrm{~km}$ away from Camerino). This, fortunately, like the previous ones, did not cause any victims, as the historic centre was almost empty and because the most important damages had already been recorded in the previous days. A further earthquake seismic swarm hit the town on January 18th, 2017, with its epicentre in Capitignano, in the province of L'Aquila, about 72 $\mathrm{km}$ from Camerino, causing a slight aggravation of the crack picture of some buildings in the historic centre, also due to the considerable distance from the epicentre.

\section{SPEDITIVE ANALYSIS OF DAMAGES IN THE HISTORICAL CENTER OF CAMERINO}

The first part of this work includes an analysis carried out through a rapid survey based on visual investigations of the damage following the 2016 earthquake. These were then compared with the data from the AeDES forms, the 1st level forms for compliance with safety standards an detection of damages during the seismic emergency used for a quick detection of damages, definition of prompt intervention measures and evaluation of the post-seismic safety of 
buildings with ordinary structural typology (masonry, reinforced concrete or steel or wood). An inspection campaign was carried out in which 249 buildings were analyzed. The investigations were carried out by completing a revised version of the STAP form used in the 1997 earthquake in order to be able to compare it with the data relating to the damage levels detected in the previous earthquake. For the types of damage and for the classification of the same, reference was made to paragraph 2.2 of Annex B to the D.G.R. Marche region n. 2153 of 09/14/1998.

The observed damages can be classified into [7]:

- Damage to masonry

- Detachment between the structural elements

- Floors, arches and lintels collapses

- Foundation settlements

- Hammering

- Collapse, even partial, of the structural elements

For the definition of the damage levels, reference was made to the following table (Figure 4):

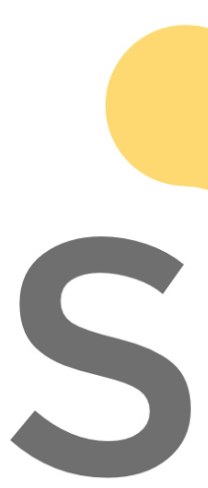

DANNO ( $F=$ crollo, $\mathbf{E}=$ gravissimo, $\mathrm{D}=$ grave, $\mathrm{C}=$ medio, $\mathrm{B}=$ leggero, $\mathbf{A}=$ nullo $)$

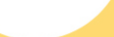

MURATURA O MISTO

Tipologie di danno

(par 2.2 e 5 alla D.G.R. delle Marche n. 2153 del 14.09.98

"Modalità e procedure per la concessione dei contributi

previsti dall'art.4 della L.N.

Danni ai maschi murar

Lesioni di distacco fra gl

Dissesti negli orizzontamention

Cedimenti

Martellamenti

Crolli, anche parziali, degli elementi strutturali
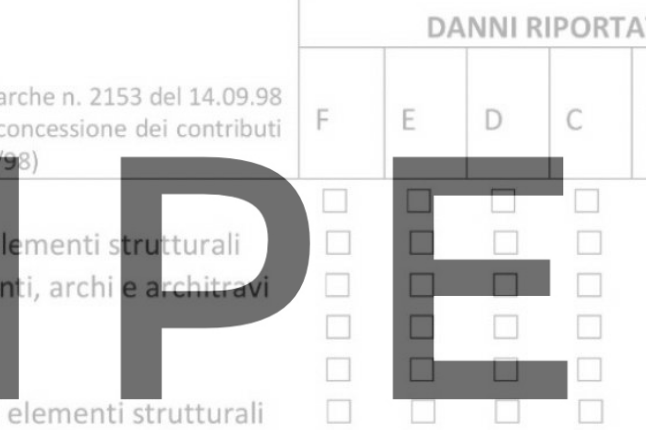

Edifico in muratura: si sono verificati martellamenti con edifici adiacenti?

NO $\square$

Figure 4: STAP form for the evaluation of the damage level

The damage levels are detected through the archiving method and provide a classification based on 5 degrees from the most serious (total collapse) to the lowest (zero damage). All visible damages were assessed - building by building - and classified according to each damage level which is represented with a different colors. The mapping of the damage levels (Figure 5) shows a difference in behaviour between the various areas of the historic centre: most of the buildings $(70 \%)$ are classified in the worst categories (serious and very serious damage with partial collapse). These levels of damage justify the extent of the red zone also following certain safety measures.

Some building clusters in the central area already restored following the 1997 seismic events, resisted better than other clusters in which the consolidation interventions had not been carried out or the works had been partially carried out. Furthermore, the most damaged 
buildings, as also occurred in other historic centres, such as in Norcia, the most damaged buildings are special buildings, churches, monasteries and large historic buildings, such as Ducal Palace, headquarters of the University. Specialist buildings have a particular performance to seismic actions which can be described using studies that highlight typical and specific vulnerabilities, recurring the abacus of damage mechanisms for non-ordinary construction types, such as such as churches, fortifications or palaces [8].

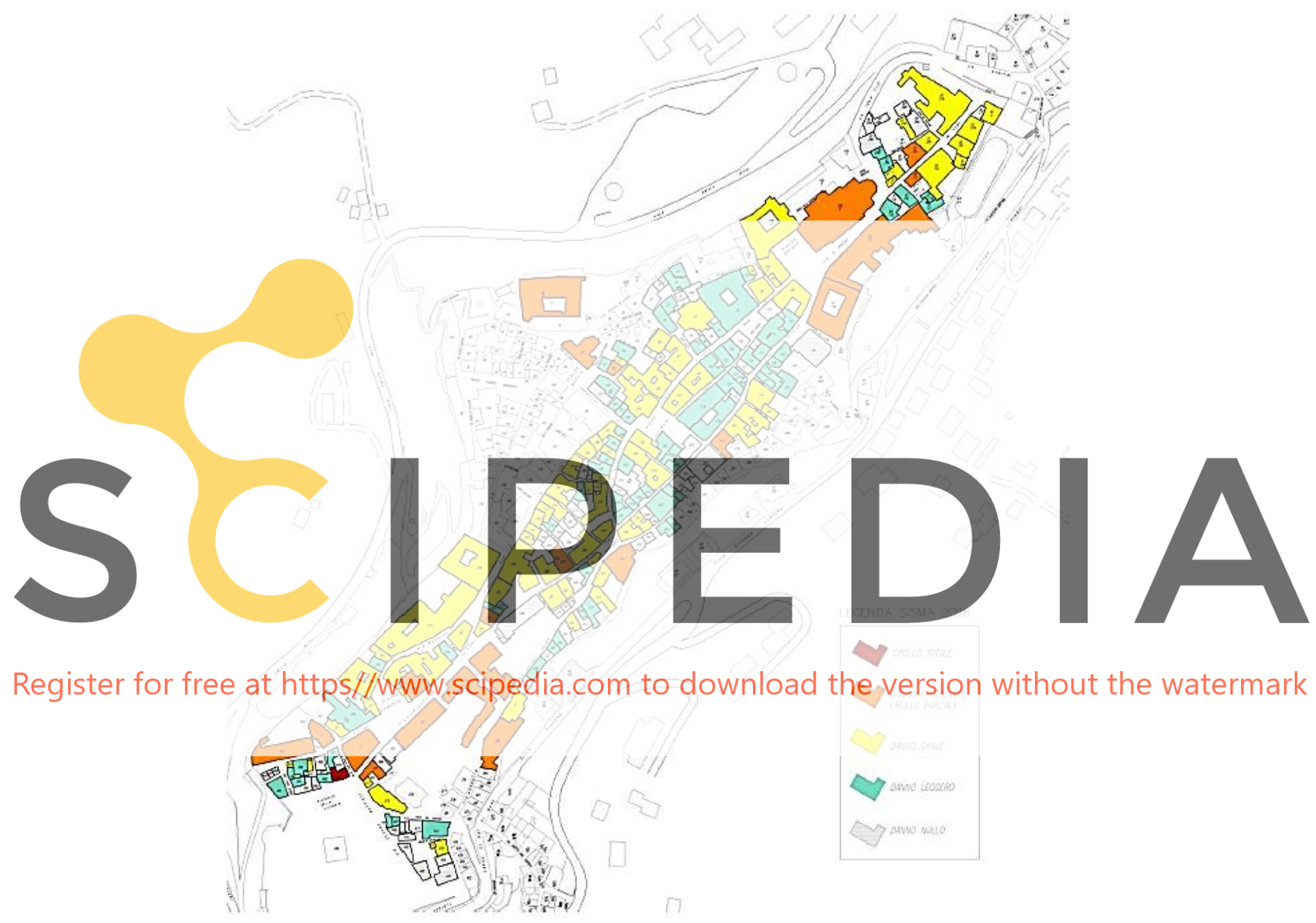

Figure 5: Representation of the levels of damage detected through the filing method (elaboration from QGis Platform, 2019)

\section{PILOT STUDY OF A BUILDING CLUSTER}

The second phase of the research proposes a different method of analyzing the damage referred to the historical centre. In fact, starting from the assumption that it was not possible to access the single structural units, the AeDES forms were used. They are first damage detection forms made by professionals in charge who carried out an inspection to estimate the extent of the damage and the safety of the buildings. 
A pilot building cluster was identified in which enough information was available to be able to compare it with the damage map previously shown. In order to compare them, each structural unit was evaluated on the severity of damage and the results of the AeDES forms. Specifically, the results reported in the sheets are as follows:

A - safe building

B - building temporarily unusable (in whole or in part) but accessible with emergency measures

C - partially unusable building

D - temporarily unusable building to be reviewed in-depth

E - unusable building

F - building unusable due to external risk

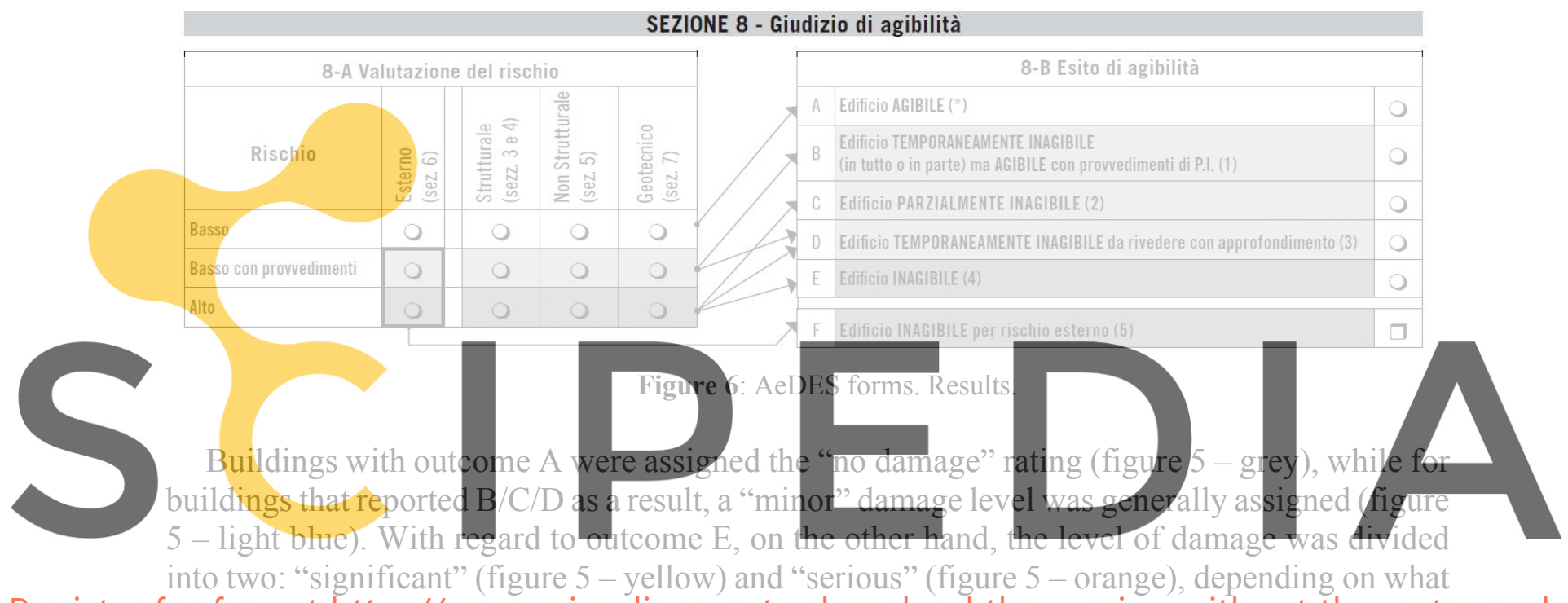

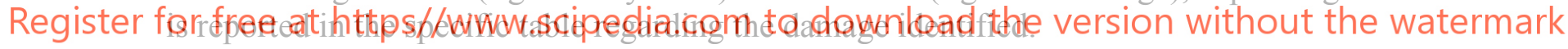

\begin{tabular}{|c|c|c|c|c|c|c|c|c|c|c|c|}
\hline \multicolumn{2}{|r|}{ Jiveile-estensious } & \multicolumn{10}{|c|}{ Danno (1) } \\
\hline & Liveiiu-esiensiuile & \multicolumn{3}{|c|}{$\begin{array}{c}\text { D4 - D5 } \\
\text { Gravissimo }\end{array}$} & \multicolumn{3}{|c|}{$\begin{array}{c}\text { D2 - D3 } \\
\text { Medio Grave }\end{array}$} & \multicolumn{3}{|c|}{$\begin{array}{c}\text { D1 } \\
\text { Leggero }\end{array}$} & \multirow[b]{2}{*}{ 을 } \\
\hline \multirow{2}{*}{\multicolumn{2}{|c|}{$\begin{array}{l}\text { Componente } \\
\text { strutturale- } \\
\text { Danno preesistente }\end{array}$}} & $\underset{\wedge}{\stackrel{m}{N}}$ & $\begin{array}{l}\stackrel{m}{\sim} \\
1 \\
\stackrel{n}{1}\end{array}$ & $\stackrel{m}{\stackrel{m}{v}}$ & $\underset{\wedge}{\stackrel{\infty}{N}}$ & $\begin{array}{l}\stackrel{m}{\sim} \\
1 \\
\\
=\end{array}$ & $\stackrel{m}{\vec{v}}$ & $\underset{\wedge}{\stackrel{m}{N}}$ & 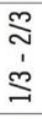 & $\stackrel{m}{\mathrm{v}}$ & \\
\hline & & A & B & C & $D$ & $\mathrm{E}$ & $\mathrm{F}$ & G & H & 1 & $\mathrm{~L}$ \\
\hline 1 & Strutture verticali & $\square$ & $\square$ & $\square$ & $\square$ & $\square$ & $\square$ & $\square$ & $\square$ & $\square$ & $\mathrm{O}$ \\
\hline 2 & Solai & $\square$ & $\square$ & $\square$ & $\square$ & $\square$ & $\square$ & $\square$ & $\square$ & $\square$ & $\mathrm{O}$ \\
\hline 3 & Scale & $\square$ & $\square$ & $\square$ & $\square$ & $\square$ & $\square$ & $\square$ & $\square$ & $\square$ & $\mathrm{O}$ \\
\hline 4 & Copertura & $\square$ & $\square$ & $\square$ & $\square$ & $\square$ & $\square$ & $\square$ & $\square$ & $\square$ & $\mathrm{O}$ \\
\hline 5 & Tamponature - Tramezzi & $\square$ & $\square$ & $\square$ & $\square$ & $\square$ & $\square$ & $\square$ & $\square$ & $\square$ & $\mathrm{O}$ \\
\hline 6 & Danno preesistente & $\square$ & $\square$ & $\square$ & $\square$ & $\square$ & $\square$ & $\square$ & $\square$ & $\square$ & 0 \\
\hline
\end{tabular}

Figure 7: AeDES forms. Evaluation of damages.

The identification of the damage is shown below, comparing it with the system used in the previous paragraph with the pilot cluster. As can be seen from figure 8 , the results obtained from the two types of expeditious analyzes are consistent in the presence of the damage, but, as 
we can see, in the map on the upper right corner (the one relating to the global survey carried out through external inspections) the damage appears to be underestimated. Specifically, there are buildings that apparently have not suffered any damage outside, however, they are unusable.

From the investigations carried out on the whole historical centre of Camerino, this inhomogeneity of the damage between inside and outside is due to the great inhomogeneity of the elements constituting the masonry (mortar and brick). The walls are, in fact, mainly double leaves walls, which cannot be analyzed as a monolithic wall as it is made up of three distinct parts (the two leaves and the internal core generally made up of inconsistent material). The two vestments, moreover, are often not connected to each other and this generates a different behaviour between inside and outside. In clusters, moreover, the connection between the walls is often non-existent or weak.

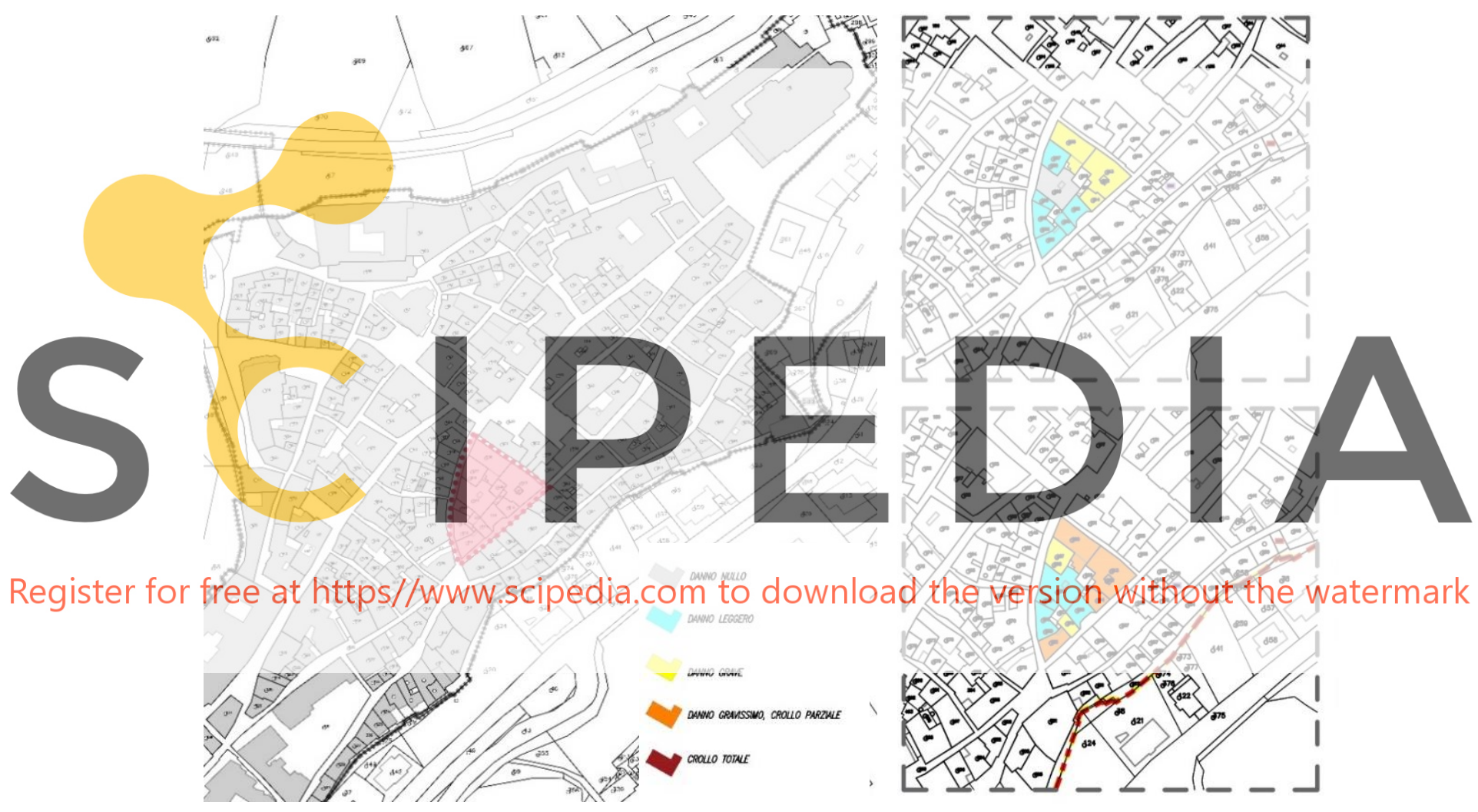

Figure 8: Comparison of the results of the two expeditious investigations. The global survey in the upper right corner and AeDES forms analysis in the lower right corner.

All these changes over time are reflected in the various types of masonry. They have been classified, following what established by the Ministerial Circular n.7/2019 (Instructions for the application of the technical standards for buildings update).

The masonry works are listed according to 8 typologies, some well-built others with limited respect for the "regola dell'arte" and therefore with a low Masonry Quality Index (IQM) [9]:

a. Chaotic stone masonry (pebbles, erratic and irregular stones);

b. Brickwork with rough-hewn segments, with uneven wall thickness;

c. Split stone masonry with good texture; 
d. Uneven soft stone masonry (tuff, calcarenite, etc.);

e. Smooth-block masonry of soft stone (tuff, calcarenite, etc.);

f. Squared stone block masonry;

g. Solid brick masonry and lime mortar;

h. Semi-solid brick masonry with cement mortar.

Each of them, recurring throughout the historic centre, systematically presents modifications, fillings, changes of material, the result of the various interventions carried out over the centuries.
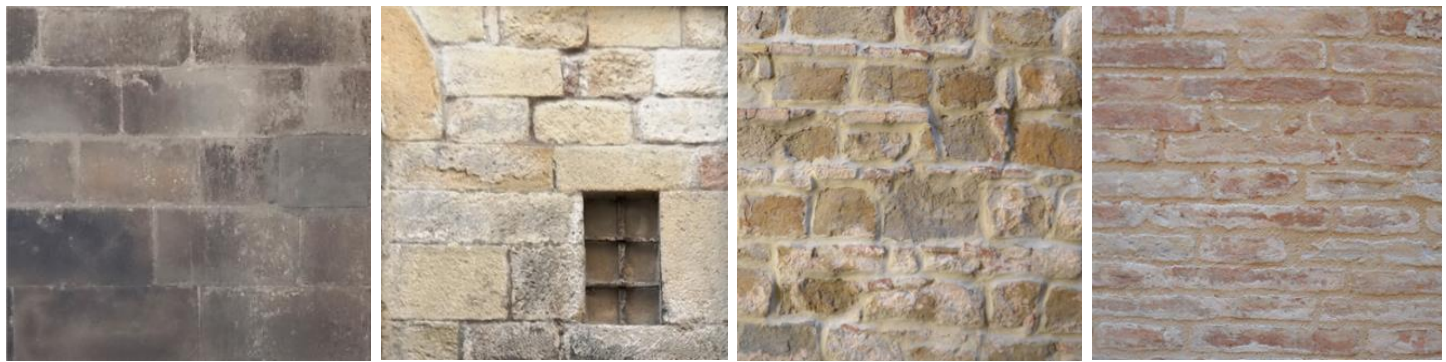

Figure 9: The most common types of masonry in Camerino: 1 - f) Masonry with square stone blocks; 2- e) Regular-block masonry of soft stone (tuff, calcarenite, etc.); 3 - c) Split stone masonry with good texture; 4 - g)

Solid brick masonry and lime mortar.

The masonry analyses are particularly complex and further interpolations are needed to compare the data collected with the expeditious method for the recognition of the damage which may not be sufficient to give a real response to quantify the seismic vulnerability in an urban context, such Camerino historical centre.

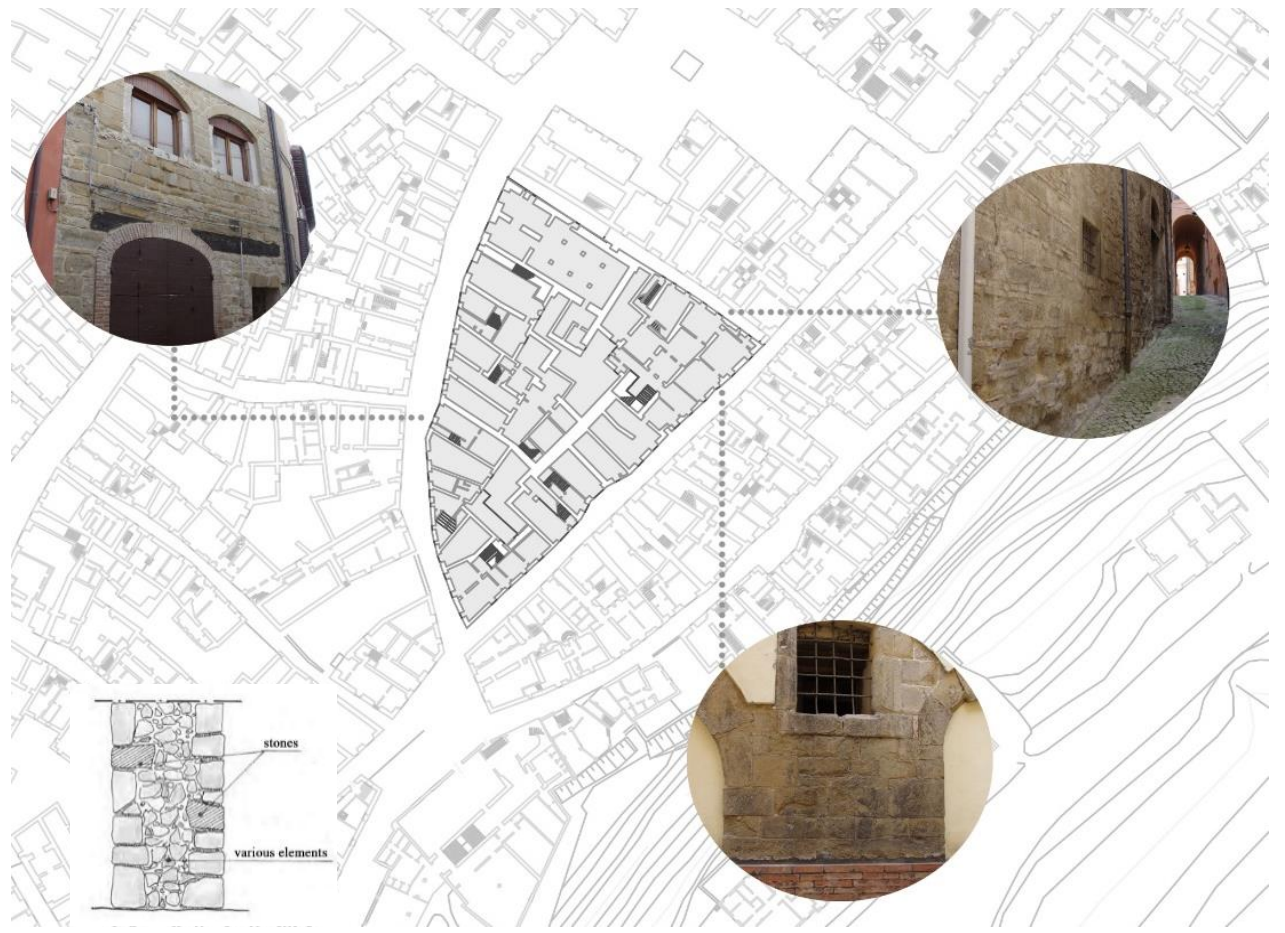

Figure 10: Characteristic walls of the pilot cluster, consisting of terraced typological units, in some cases recast into more complex buildings that show evident signs of transformations (Elaboration Barchetta, 2019). 


\section{CONCLUSIONS}

Starting from what is observed in this article, the analysis of local vulnerabilities should be divided into three in-depth phases: knowledge, analysis and evaluation [10]. The assessment of the damage suffered by the historic centre of Camerino after the aftershocks of the 2016-2017 seismic sequence is a good starting point for identifying the recurrent mechanisms. The expeditious analysis of the damage that is proposed here is a good basic method but the actual extent of the same is underestimated and therefore the results do not fully agree with what emerges from direct observation. For an optimal response, however, the cross-reading of the different information from various sources can allow a more precise assessment, to be put in relation with the actions aimed at ensuring the development of a new resilience for the reduction of vulnerability in historic centres, taking into account typical and specific peculiarities that represent the identity value that characterizes the internal areas of the Marche, of which Camerino is one of the most emblematic cases.

\section{REFERENCES}

[1] Galderisi A., Ceudech A., Resilienza e vulnerabilità dei sistemi urbani. una proposta di metodo per la mitigazione del rischio sismico. In XXIV Conferenza Italiana di Scienze regionali, Perugia 8-10 Ottobre 2003, 1-24.

[2] D'Amico A., Currà E., Urban Resilience in the Historical Centres of Italian Cities and Towns. Strategies of Preventative Planning. TECHNE - Journal of Technology for Architecture and Environment, 15, 2018, 257-268.

[3] Petrucci E., Le alterazioni del linguaggio nell'emergenza post-sisma. Ricostruzione o abbandono. In E. Petrucci, L. Romagni (Eds), Alterazioni. Osservazioni sul conflitto tra antico e nuovo, Quodlibet, (2018), 45-73.

[4] Lombardo G., Greco A., Caddemi S., La vulnerabilità sismica degli edifici storici in aggregato. Nuove metodologie negli approcci speditivi e di modellazione strutturale, Edizioni Efesto, (2018), 9-14.

[5] Mochi G., Predari G., La vulnerabilità sismica degli aggregati edilizi: una proposta per il costruito storico, Edicom (2016)

[6] Savini P., Storia della città di Camerino, Tipografia Savini, II ed.,1895, 34-42.

[7] De Felice G., Pugliano A., Il lessico costruttivo dell'edilizia storica. In A. Giuffre (Ed.), Sicurezza e conservazione dei centri storici. Il caso di Ortigia, Editori Laterza, (1993), 6999.

[8] Ferrigni F., et al., Ancient buildings and earthquakes The local Seismic Culture approach: principles, methods, potentialities, Edipuglia, (2005).

[9] Borri A., De Maria A., 2019. Qualità muraria secondo il metodo IQM: aggiornamento alla Circolare esplicativa n.7 del 2019. Structural. Building Engineering+ Structural Design, 222, marzo-aprile 2019, 1-21, https://doi.org/10.12917/STRU222.07.

[10] Agostiano M., Concas D., La conoscenza del patrimonio culturale fondamentale per la conservazione in sicurezza: la verifica di vulnerabilità sismica. In: A. Aveta (Ed.), RICerca/REStauro, Sez. 3B: Progetto e cantiere: problematiche strutturali, Edizioni Quasar, (2017), 782-792. 